\title{
Tendentious Modernism: Karel Teige's Path to Functionalism
}

\author{
Peter Zusi
}

The category of tendentiousness - with its dogmatic, didactic, and aesthetically conservative inclinations - seems inherently opposed to the logic of modernism, which emphasized the aesthetic moment of formal innovation. While many modernists argued for the compatibility between aesthetic and political revolution, they invariably met the skepticism of those demanding a clear, unambiguously expressed political message from art. But was this conceptual divide unbridgeable? In this article, Peter Zusi explores this question through the case of the Czech theorist of the interwar avant-garde, Karel Teige. Teige exemplifies how the early Czech avant-garde adopted such terms as function and popular character (lidovost) from nineteenth-century Czech discourse, where they had served to celebrate the tendentious applicability of cultural artifacts to a political movement of emancipation. For Teige, however, these terms quickly shifted from accentuating to critiquing political tendentiousness. Teige's shift, Zusi argues, does not represent the trace of cultural belatedness or conceptual confusion as much as it reveals the flexibility of conceptual oppositions too often conceived as static.

\section{A "Polyphony of Voices"? Czech Popular Opinion and the Slánský Affair}

\section{Kevin McDeRmott}

The trial of Rudolf Slánský and his thirteen codefendants in Prague in November 1952 represented the culmination of Stalinist political terror in postwar central and eastern Europe. Ever since, it has attracted much scholarly attention focusing largely on the origins, processes, and outcomes of the trial. In this article, Kevin McDermott examines a crucial, but almost totally unresearched aspect of the affair: Czech popular reactions to Slánskýs arrest and trial. Using documents from the Central Committee of the Communist Party of Czechoslovakia and secret police reports from the Ministry of Interior archives, McDermott demonstrates that popular opinion was extremely diverse, ranging from strident and selective support of the official version of the court proceedings; to passive compliance and resigned accommodation; to apathy, guarded dissent, and overt opposition. Two findings are particularly noteworthy: first, virulent antisemitic sentiment was endemic; and second, many workers, rankand-file party members, and even lower-level functionaries were highly critical of the country's communist leaders. In conclusion, McDermott proposes that the archival record reveals the relatively broad diffusion of antisemitism in Czech society, the limits of the "Stalinization" process in the Czechoslovak party, and the failure of Stalinist terror to intimidate the population in to submission and eradicate independent thinking. 


\section{Casualties of Conflict: Crimean Tatars during the Crimean War}

\section{MARA KOZELSKY}

During the Crimean War, Crimean Tatars were charged en masse with collaborating with the Allies. At the war's conclusion, nearly 200,000 Tatars left the peninsula to relocate in the Ottoman empire. Mara Kozelsky contributes to an understanding of this critical episode in the Crimean War by examining secret surveillance documents, a collection that records complex state attitudes toward Tatars from the Allied landing on the Crimean coast to the Treaty of Paris. These documents reveal that intelligence operations provided no evidence of a collective Tatar guilt and instead testified to the diversity of pressures on state policies toward subject populations on the front lines of battle. Shifting wartime conditions, religious tensions, and repeated crises at the front highlighted unresolved debates about religion and loyalty to the state. Some officials recommended deporting the Tatars, others encouraged their migration, and still others advocated on the Tatars' behalf.

\section{Freud, Tatlin, and the Tower: How Soviet Psychoanalysts Might Have Interpreted the Monument to the Third International}

\section{Alexei Alexeyevich Kurbanovsky}

The first translations of Sigmund Freud's texts into Russian appeared in the early 1900 s, and by the 1920s all important works were available; in Soviet Russia they stimulated wide discussion of various medical, pedagogical, and social problems as well as of developments in creative art. Alexei Kurbanovsky argues that "Freudianism" would have seemed very tempting to those early Soviet theorists who believed that they must appropriate the relevant discoveries of western psychology and adopt them for their own revolutionary ends: creating the "new communist man." The application of Freudian techniques to the analysis of some classical Russian writers as well as painters is documented in writings from the 1920s by Ivan Ermakov; the artistic tendencies of the Russian avant-garde were quite often viewed as reflecting the latest achievements of science and technology. So aspiring Soviet critics might well have attempted psychoanalytical "readings" of innovatory artifacts. Vladimir Tatlin stands as one of their possible model cases. Kurbanousky argues that Tatlin's famous spiral tower could be psychoanalytically interpreted in reference to the Oedipal "refutation of father-figures." Such an interpretation seems in tune with the general cultural climate where other phenomena (such as the October revolution) were seen as having a "hidden, Freudian aspect." Examining the psychoanalytical underpinnings of the theory of Soviet avant-garde allows us to more fully appreciate its historical and cultural significance. 
Art, Nationhood, and Display: Zinaida Volkonskaia and Russia's Quest for a National Museum of Art

\section{Rosalind P. BLAKESLEY}

In 1831, the journal Teleskop published Princess Zinaida Volkonskaia's proposal for a national art museum in Moscow. Volkonskaia's project was progressive to a degree (Russia had no such museum at the time), yet the model she proposed was highly traditional. She excluded Russian art entirely, despite her support of modern Russian artists. Instead, Volkonskaia privileged classical and more recent western European art, underlining the deference to western practice that influenced cultural politics even as Russia moved toward a stronger national sense of self.

Volkonskaia's project marks an important juncture in Russia's cultural history: the intersection of aristocratic female patronage and the institutionalization of academic procedure. It also provides a platform from which to consider Russia's self-image vis-à-vis Europe in the aftermath of the Napoleonic campaigns. By tracing an intricate dialogue in which national pride developed alongside continuing admiration for neoclassical ideals, Rosalind P. Blakesley addresses the paradoxes of Volkonskaia's project, and the difficulties of conceptualizing a "national" space of artistic display. Volkonskaia's project poses significant interpretive problems and her exclusion of Russian art prefigures the segregation of Russian and western art in Russian museums today, which has marginalized Russian art even within Russia itself. Volkonskaia's project thus has wide resonance, for the question of whether and how museums encapsulate national cultural identities remains an issue of great intellectual concern.

\section{Pictures at an Exhibition: Science, Patriotism, and Civil Society in Imperial Russia}

\section{JOSEPH BRADLEY}

Organized by a Moscow learned society, the Polytechnical Exposition of 1872 helped mobilize resources for popularizing science that connected tsarist officialdom, the Moscow municipal government and business community, university scientists, and other private associations. Although the relationship between the autocratic government and society is often portrayed in terms of conflict, partnership was more typically the rule, especially in the effort to build a native science infrastructure. The grand exhibitions of science and industry of the nineteenth century were sites of modernity that displayed visions of progress, created a public culture, and fashioned national identity. Moscow's Polytechnical Exposition juxtaposed the modern and the foreign with the traditional and the Russian in order to demonstrate that Russia could have modern science and technology without abandoning its traditional culture. Paradoxically, to assert its place in European civilization in an age of nationalism and imperialism, Russia had to assert its Russianness - its cultural distinctiveness, patriotism, and imperial pride. With its emphasis on change and progress, as well as on traditional Russian culture, the exposition fostered a Russian 
public aware of its place in a changing world, of its place in history, of its identity as a nation.

\section{Models of Selfhood and Subjectivity: The Soviet Case in Historical Perspective}

\section{Choi Chatterjee and Karen Petrone}

In this essay Choi Chatterjee and Karen Petrone examine some of the paradigms of selfhood that western scholars have used to understand Soviet subjectivity. They start with an analysis of how racialized western discourses about the backward Russian national character were transformed into representations of the totalitarian Soviet self seen as a passive receptacle for the ideological excesses of the regime. Revisionist historians have argued against this model and have shown how the pragmatic Soviet subject both internalized and resisted the Soviet norms of selfhood. In the third wave, scholars have used the model of the normative self to plot the internal processes through which citizens attempted to align their souls with the demands of Stalinist ideology. Chatterjee and Petrone conclude with the scholars' analysis of the banal self, or the situation of Soviet selfhood in intimate and private spheres of existence that necessitated multiple negotiations and compromises with the theoretical norms of statesponsored subjectivity. 